\title{
Growth and Longevity of Blue Grama Seedlings Restricted to Seminal Roots
}

\section{H. VAN DER SLUIJS AND D. N. HYDER}

Highlight: Contrary to previous indications, this study shows that there is no inherent limit to the longevity of seminal roots of blue grama seedlings. When restricted to seminal primary roots, blue grama seedlings grew actively in the greenhouse for 22 weeks. Tillering began at 3 weeks and continued at a linear rate of 0.165 tillers per day. Leaf length on primary shoots reached a maximum of about $80 \mathrm{~cm}$ at 6 to 7 weeks and decreased by death of older leaves thereafter. Total leaf length of tillers reached a maximum of 250 to 350 $\mathrm{cm}$ of green tissue at 13 to 14 weeks. The water-transport capacity of the subcoleoptile internode apparently prevented further leaf expansion. Since field conditions impose sudden increases in transpirational stress, it may be necessary to restrict leaf expansion until adventitious roots are well established.

Blue grama (Bouteloua gracilis (H.B.K.) Lag. ex Steud.) is well adapted to grazing and semiarid conditions on the

The authors are research assistant, Colorado State University, and range scientist, U.S. Department of Agriculture, Agricultural Research Service, Fort Collins, Colorado. The senior author's present address is Office of Director (Rm. C415), Latin America and Caribbean Region, International Bank for Reconstruction and Development, $1818 \mathrm{H} \mathrm{St}$., N.W., Washington, D.C. 20433.

The study involves cooperative investigations of the Agr. Res. Serv., U.S. Dep. Agr., and the Colorado Agricultural Experiment Station, Fort Collins. (Scientific Series Paper No. 1870.)

Manuscript received J une 29, 1973.
Shortgrass Plains of Colorado and Wyoming. The paradox is that blue grama is poorly adapted for natural regeneration from seed on the rangelands where it is the ecological dominant (Hyder et al., 1971). When planted in warm, moist soil, blue grama seeds germinate quickly, and seedlings emerge in 4 or 5 days, but seedling establishment is rare. In field seedings at the Central Plains Experimental Range near Nunn, Colo., blue grama seedlings died at about 6 to 8 weeks of age, unless adventitious roots were extended. Weaver and Zink (1945) reported that under optimal conditions in the greenhouse, blue grama seedlings grown entirely on primary seminal roots invariably died within 9 weeks. Those results suggest that blue grama seedlings may have an inherent limit to longevity when restricted to seminal roots.

Two types of grass seedlings are recognized (Hyder, 1973). Wheatgrasses have a long coleoptile that extends from the seed to the soil surface after emergence; whereas blue grama has a short coleoptile that is elevated to the soil surface by elongation of a subcoleoptile internode. The blue-grama form places the coleoptilar node and all tillering crowns, from which adventitious roots may arise, on or very near the soil surface. Consequently, adventitious roots grow out of the tillering crowns only when damp, cloudy weather persists for 2 or 3 days. Since plant establishment depends ultimately on the 
extension of adventitious roots (Esau, 1960), the longevity of seedlings restricted to seminal roots might be critical to seeding success where the soil surface generally remains hot and dry. Greater seedling longevity would provide a longer period of time during which precipitation may favor the growth of adventitious roots. Seedling longevity might be increased by genetic selection. Otherwise, improvement in seeding success is limited to cultural practices that modify micro-environmental conditions or plant characteristics.

We considered the possibility of an inherent limit to seedling longevity primarily because the subcoleoptile internode is a very slender thread. Deterioration and loss of function in the subcoleoptile internode could stop the flow of water and nutrients from root to shoot or the flow of photosynthates from shoot to root. If the capacity for transport through the subcoleoptile internode decreases with an increase in length, seedling development and longevity may be directly related to planting depth. Consequently, the development and longevity of blue grama seedlings grown from seed planted at varying depths and restricted to seminal primary roots was evaluated under favorable conditions in the greenhouse.

\section{Methods}

Blue grama seedlings were grown in plastic pots $15 \mathrm{~cm}$ in diameter from seed planted in sterilized soil. Total depth of soil in the pots was $12 \mathrm{~cm}$. Twenty seeds were planted at depths of $5,10,15,20$, and $25 \mathrm{~mm}$ in each of five pots per planting depth on September 6,1972. The upper $5 \mathrm{~mm}$ of the profile in all pots consisted of perlite. The seedlings emerged in 3 to 6 days and were thinned to a uniform stand of five per pot 12 days after planting. Subsequently, all seedlings were checked every other day by removing the perlite from the base of the seedlings with a gentle air spray. Adventitious roots were excised if present. Plants were subirrigated to maintain optimum growing conditions. Temperatures during the experiment fluctuated from about 27 to $30^{\circ} \mathrm{C}$, and the day length decreased from 13 hours during the early stages of growth to 9 hours 15 minutes in December.

At 4 weeks from planting, the perlite was removed, and each plant was provided with aluminum-foil disks of $2.5 \mathrm{~cm}$ diameter to stop adventitious roots. Two disks slit to the center were placed around a subcoleoptile internode below the crown so that the slits did not overlap (Fig. 1). A 5-mm layer of small gravel was placed over the disks to support the seedlings and reduce evaporation from the soil surface.

When the plants were 47 days old, three matching replicate pots were selected for each planting depth and thinned to three plants per pot. These plants were observed weekly to determine the number of tillers per plant and the total green-leaf-blade length on primary shoots and tillers. Plants from other replicates were observed for rate of adventitious rooting.

\section{Results and Discussion}

\section{Seedling Longevity}

Blue grama seedlings restricted to primary seminal roots did not show an inherent limit to longevity. A large number of plants grew actively for 22 weeks.

A few plants that died in the first three weeks appeared to be infected by foot-rot organisms in the subcoleoptile internodes. Some older plants were lost when the subcoleoptile internodes were broken during leaf measurements. A single plant apparently broke its own subcoleoptile internode as a mass of tillers, crowded for space, pressed against the soil. The

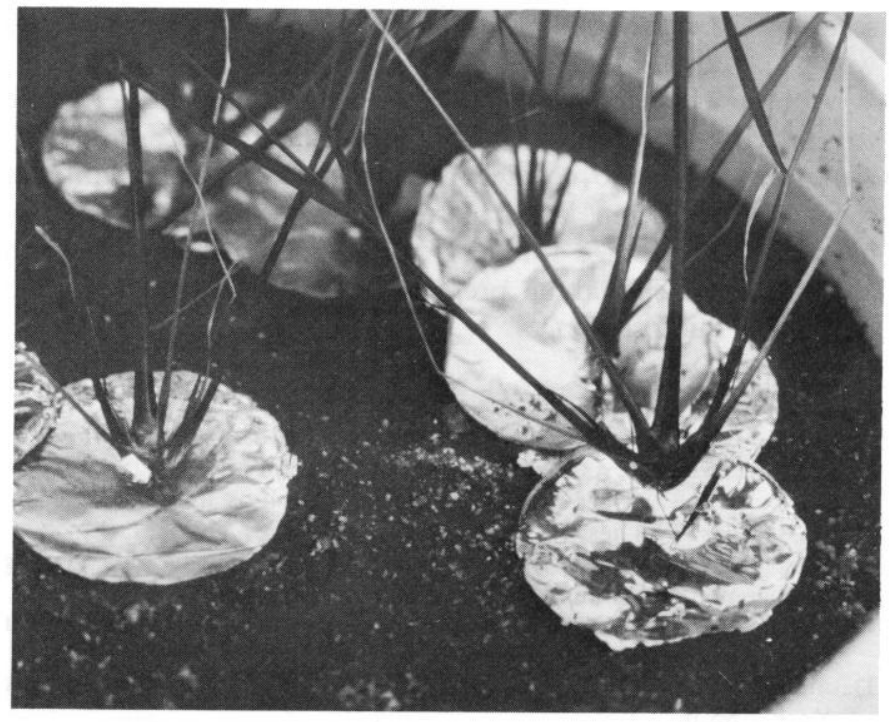

Fig. 1. Ten-week-old seedlings grown entirely on seminal primary roots with aluminum-foil disks around the subcoleoptile internodes. The disks were covered with gravel to support the seedlings and minimize evaporation.

subcoleoptile internode is a thin, delicate member (Fig. 1), and breakage could surely occur in the field as a result of wind and animal activity.

\section{Seedling Growth and Development}

The rate of tillering was independent of planting depth. Tillering began consistently at 20 days of age, and tillers formed at a linear rate of 0.165 per day. Thus, the plants had an average of 15 tillers at 16 weeks (Fig. 2).

Leaf length for the primary shoot was independent of planting depth, reached a maximum of about $80 \mathrm{~cm}$, and decreased by death of older leaves after 7 weeks. The total leaf length of tillers increased in a curvilinear manner and reached

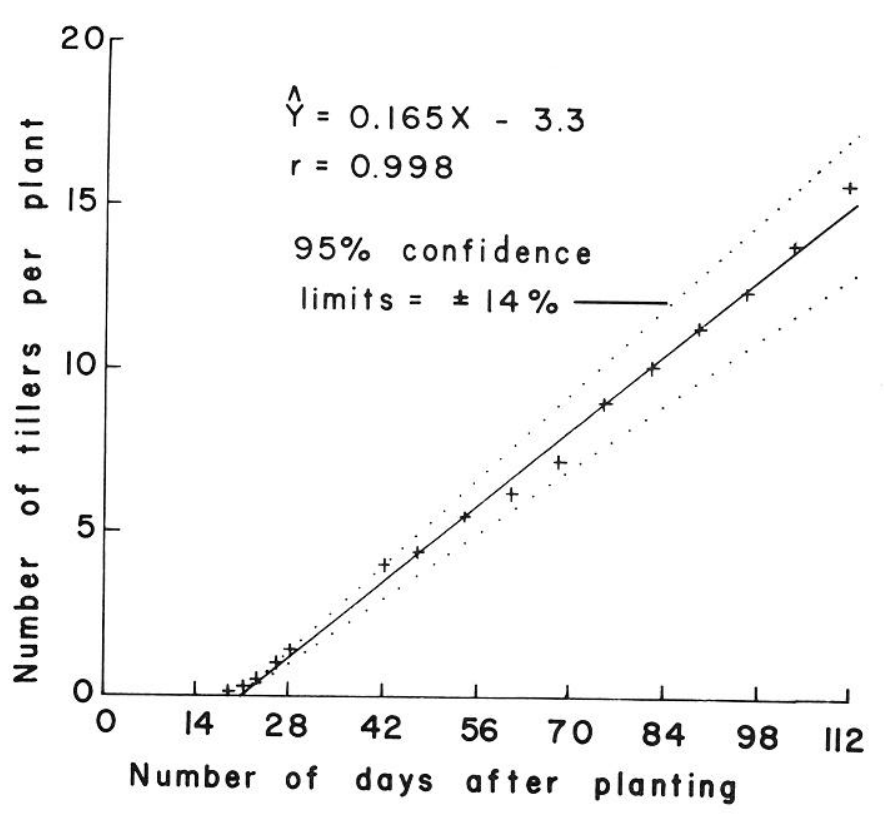

Fig. 2. Increase in number of tillers on blue grama seedlings restricted to seminal primary roots. 
maximum at about 13 weeks (Fig. 3). Older leaves died back from the tips as new leaves appeared. Seedlings planted at less than $20 \mathrm{~mm}$ produced about $9 \mathrm{~cm}$ more leaf blade per weck than those planted at greater depths. The total leaf lengths of tillers $(250-350 \mathrm{~cm} /$ plant $)$ were surprisingly large, considering the plants' dependence on water transport from the primary root through the subcoleoptile internode.

We interpret these maximum leaf lengths (and leaf areas amounting to $0.13 \mathrm{~cm}^{2}$ of upper surface per $\mathrm{cm}$ of leaf length) as limits imposed by the rate of water transport through the subcoleoptile internode. Since field conditions impose sudden increases in transpirational stress, it may be necessary to restrict leaf expansion until adventitious roots are well established.

\section{Development of Adventitious Roots}

The first adventitious roots were observed and excised from six seedlings 11 days after planting at a depth of $5 \mathrm{~mm}$. Sixty percent of the plants had initiated adventitious roots by the 14 th day, and all healthy seedlings were capable of rooting by the 20th day. Those prevented from adventitious rooting by dry surface of perlite or gravel were tested for rapidity of rooting after the age of 3 weeks. Aventitious roots appeared within a few hours after the tillering crowns were exposed to moist soil. The average maximum rate of adventitious root growth was $3 \mathrm{~cm}$ in 24 hours. Consequently, improvement of the microenvironment at the soil surface (by precipitation or cultural treatment) for 2 or 3 days when seedlings are 3 to 6 weeks of age should assure extension of adventitious roots.

\section{Conclusions}

These results suggest two factors that should be considered in the development of better seeding practices. First, it may be appropriate to consider restricting leaf expansion, to prevent overextending the water-transport capacity, until adventitious roots are well established. Secondly, it may be appropriate to

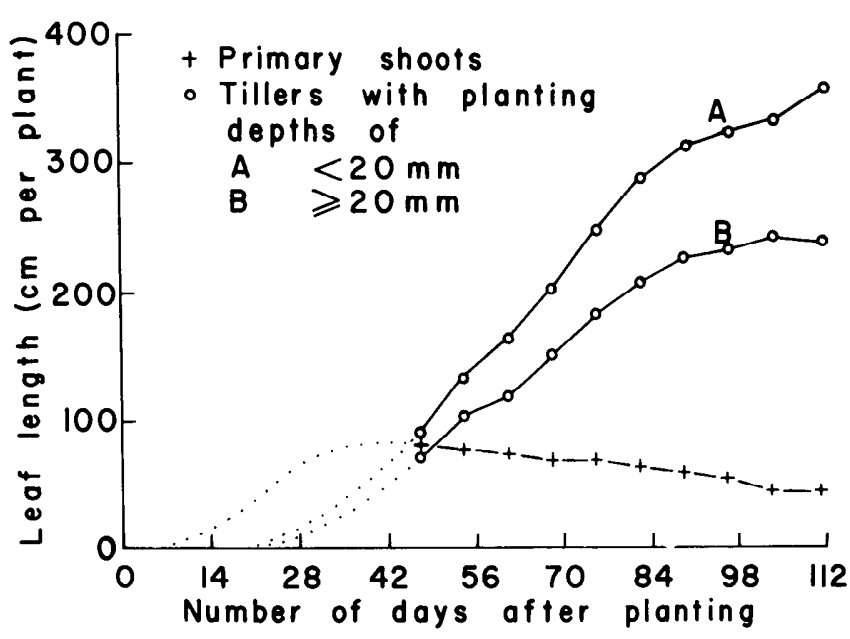

Fig. 3. Leaf growth on primary shoots and tillers of blue grama seedlings restricted to seminal primary roots. The dotted parts of lines extrapolate leaf-length measures to time of origin.

consider burying the crowns of seedlings, and/or irrigating lightly along the rows, to promote adventitious roots. Each of these considerations involve time of seeding with reference to seasonal changes in evaporation and transpiration.

\section{Literature Cited}

Esau, K. 1960. Anatomy of seed plants. John Wiley and Sons, Inc., New York. 170 p.

Hyder, D. N., A. C. Everson, and R. E. Bement. 1971. Seedling morphology and seeding failures with blue grama. J. Range Manage. 24:287-292.

Hyder, D. N. 1973. Morphogenesis and management of perennial grasses in the United States. In Proceedings of U.S./Australian Range Science Workshop held in Berkeley, California, March 29-April 6, 1971. U.S. Dep. Agr. Misc. Publ. 1271.

Weaver, J. E., and E. Zink. 1945. Extent and longevity of the seminal roots of certain grasses. Plant Physiol. 20:359-379.

\section{ㅁㅁㅁㅁ}

\section{SRM 28th Annual Meeting}

- Maria Isabel-Sharaton

- Mexico City

- February 4-9, 1975

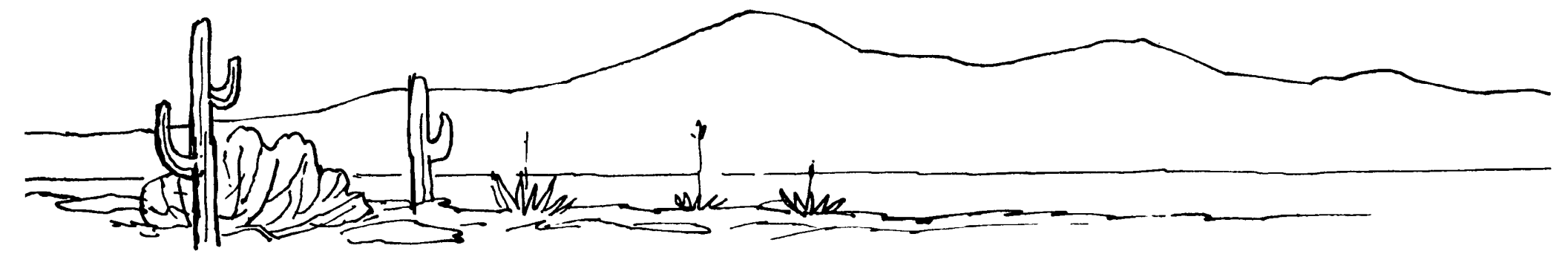

